\title{
STRATIGRAPHY OF WANDA GLACIER, KING GEORGE ISLAND, ANTARCTICA, USING GROUND PENETRATING RADAR
}

\author{
Kátia Kellem da Rosa' ${ }^{1}$ Guilherme Borges Fernandez ${ }^{2}$, Thais Baptista da Rocha ${ }^{3}$, \\ Felipe Lorenz Simões ${ }^{4}$, Rosemary Vieira ${ }^{5}$ and Jefferson Cardia Simões ${ }^{1}$
}

\begin{abstract}
We present the results of a high-frequency Ground Penetrating Radar (GPR) surveys carried out during the ablation season of 2011, in Wanda Glacier, King George Island (KGI), Antarctica, aimed to determine its internal structure and thermal regime. GPR data were collected along 17 longitudinal and transversal sections in the ablation area in January 2011. Migrated and topographically corrected radar sections show strong internal reflectors in firn layer. Similar internal structure is observed in other glaciers in KGl. Strong scattering of radio waves are attributed to supraglacial, englacial and subglacial meltwater channels and constitutes further evidence that the ice in the ablation area of this glacier is temperate. Because of its small size $\left(1.5 \mathrm{~km}^{2}\right)$ and thermal conditions, Wanda Glacier responds rapidly to climatic changes being relevant for environmental studies.
\end{abstract}

Keywords: glaciology, thermal regime, glacial dynamic.

RESUMO. 0 trabalho apresenta resultados de dados de GPR de alta frequência obtidos durante a estação de ablação de 2001, na geleira Wanda, Ilha Rei George (KGI), Antártica, com o objetivo de determinar a estrutura interna e o regime termal. Dados de GPR foram coletados em 17 perfis longitudinais e transversais na área de ablação em janeiro de 2011. Perfis de radar topograficamente corrigidos e migrados mostram fortes refletores internos na camada de firn. Estruturas similares foram observadas em outras geleiras da KGl. Fortes espalhamentos das ondas de rádio são atribuídas a canais de água de degelo nas zonas subglaciais, supraglaciais, e englaciais e constituem evidências para que o gelo na zona de ablação seja temperado. Devido à sua pequena dimensão $\left(1,5 \mathrm{~km}^{2}\right)$ e condições termais, a geleira Wanda responde rapidamente as mudanças climáticas, o que é relevante para estudos ambientais.

Palavras-chave: glaciologia, regime termal, dinâmica glacial.

\footnotetext{
${ }^{1}$ Centro Polar e Climático, Universidade Federal do Rio Grande do Sul, Av. Bento Gonçalves, 9500, Prédio 43136, Sala 210, 91501-970 Porto Alegre, RS, Brazil. Phone: +55(51) 3308-6341 - E-mails: katiakellem@gmail.com; jefferson.simoes@ufrgs.br

2 Instituto de Geociências, Laboratório de Geografia Física, Universidade Federal Fluminense, Av. Litorânea s/n, Campus Praia Vermelha, $5^{\circ}$ andar, sala 522 , Gragoatá, Caixa Postal: 24210-346,24210-340 Niterói, RJ, Brazil - E-mail: guilhermefernandez@id.uff.br

${ }^{3}$ Centro de Estudos Gerais, Instituto de Geociências, Universidade Federal Fluminense, Av. Litorânea s/n, Campus Praia Vermelha, 24210-340 Niterói, RJ, Brazil - E-mail: thaisitc5@yahoo.com.br

${ }^{4}$ Laboratório de Entomologia Sistemática, Departamento de Zoologia, Instituto de Biociências, Universidade Federal do Rio Grande do Sul - UFRGS, Av. Bento Gonçalves, 9500, Prédio 43435, Sala 201, 91501-970 Porto Alegre, RS, Brazil - E-mail: felipe.lorenz@ufrgs.br

${ }^{5}$ Laboratório de Processos Sedimentares e Ambientais - INCT-Criosfera, Instituto de Geociências, Departamento de Geografia, Universidade Federal Fluminense, Av. Gal. Milton Tavares de Souza, s/n, Campus da Praia Vermelha, Boa Viagem, 24210-346 Niterói, RJ, Brazil. Phone: +55(21) 2629-5951 - E-mail: rosemaryvieira@id.uff.br
} 


\section{INTRODUCTION}

Wanda Glacier is a small (total area of about $1.56 \mathrm{~km}^{2}$ ), temperate land terminus glacier located in Kraków ice field, King George Island (KGI). This island is the largest of the South Shetland Islands at the northern tip of the Antarctic Peninsula (Fig. 1).

Since 2007, systematic field activities have been carried out in Wanda Glacier. More recently, the main emphasis has been on extensive investigations of glacier hydrology and dynamics. The glacier is $1.4 \mathrm{~km}$ long, 0.4 to $1.0 \mathrm{~km}$ wide and has a mean surface slope of approximately $20 \%$ to $30 \%$. Crevasses are observed in the ablation area and subglacial conduits emerge at the glacier front.

Several recent studies have indicated that Wanda Glacier has lost 0.71 km² since 1979 (Simões \& Bremer, 1995; Rosa et al., 2009). During the last 40 years, ice caps in King George have lost $6.6 \%$ of their area (Simões \& Bremer, 1995; Simões et al., 1999; Blindow et al., 2010). Furthermore, over the past 30 years, the number of summer days with liquid precipitation has increased and the mean annual temperature increase $3^{\circ} \mathrm{C}$. These changes have accelerated the snowmelt and increased the negative mass balance of local glaciers (Braun et al., 2001; Ferrando et al., 2009).

Equilibrium line altitude (ELA) in King George Island is estimated to be between 300 and $350 \mathrm{~m}$ (Simões et al., 1999). According to Braun \& Rau (2000), the firn line elevations ranged between 160 and $270 \mathrm{~m}$ on $\mathrm{KGl}$. Over the last three decades GPR systems have been utilized to study a variety of largescale glaciological applications as internal structure investigation (Forster et al., 1991; Arcone et al., 1995; Murray et al., 1997; Arcone et al., 2004), hydraulic pattern, crevasses detection, channels water, cavities and bedrock identification, ice mass balance and thermal conditions investigation (Kohler et al., 1997; Travassos \& Simões, 2004). The knowledge of internal structure and ice content is crucial for the understanding of the glacial dynamic (Patterson, 1994).

This study proposes the use of GPR data to determine the internal structure and thermal regime of the Wanda Glacier. The glaciological characterization and monitoring of glaciers in this region is important for understanding the effects of climate regional variability.

\section{METHODS}

The Ground Penetrating Radar (GPR) sounding is an established technique for glaciological investigations. Because of the glacier ice low conductivity and hence its low dielectric loses, this is an ideal material for the propagation of electromagnetic waves
(Plewes \& Hubbard, 2001; Travassos et al., 2004). The fundamental principles of GPR are described by Daniels et al. (1988) and Davis \& Annan (1989) and detailed summaries of GPR glaciological data acquisition techniques and post-processing approaches by Daniels (1996), Plewes \& Hubbard (2001), Woodward et al. (2003), Neal (2004), Hubbard \& Glasser (2005).

Ground Penetrating Radar (GPR) data were collected along 17 longitudinal and transverse sections (Fig. 2) in the ablation area in January 2011. Sampling was based on the continuous mode and common offset data acquisition. We used a Geophysical Survey Systems, Inc. (GSSI) SIR System control unit and a $100 \mathrm{MHz}$ transceiver single ('monostatic') antenna. The antenna was polarized orthogonally to the transect and Iongitudinal directions (following the central flowline), and data were collected with a time window of 600 and $800 \mathrm{~ns}$.

GPR data were corrected with topography data and were processed using the RADAN ${ }^{\mathrm{TM}} 6.5$ software from Geophysical Survey Systems, Inc. (GSSI). Range gain was used to compensate for progressive radar-signal strength attenuation.

Glacier sections were migrated (FK migration) to collapse diffraction hyperbolas and to correct the orientation of steep dipping layers. Glacier sections were filtered to remove noise. Position correction was applied to remove depth distortions of the reflection sections upper parts and to create zero-offset traces. According to Fisher et al. (1996) time-zero must be move up the trace to the point at which the initial pulse is generated at the transmitting antenna. Distance and surface normalization for time was performed using topographic sections from total station and differential GPS data.

One radar section (L15) was processed using a gain function exponential and filter band pass and migrated, using the REFLEX software, with several parameters of the scattering hyperbolae migration velocity for analysis of the vertical velocity distribution. Radar wave velocity propagation in glaciers is highly sensitive to the presence of liquid water because of the large velocity contrast between ice $\left(0.168 \mathrm{~m} / \mathrm{ns}^{-1}\right)$ and water $\left(0.032 \mathrm{~m} / \mathrm{ns}^{-1}\right)$ (Bradford \& Harper, 2005). According to Bradford \& Harper (2005), this strong sensitivity allows us to estimate the relative water proportions along a cross-section of the glacier. The thermal conditions of the glacier were inferred based on this analysis. The possibility of detecting thermal regimes within glaciers by means of radar surveys has been established by several studies (Watts \& England, 1976; Jacobel \& Anderson, 1987; Bamber, 1988).

\section{RESULTS}

We concentrate our discussion on 4 section that illustrate the most important features of our data set. The longitudinal and 

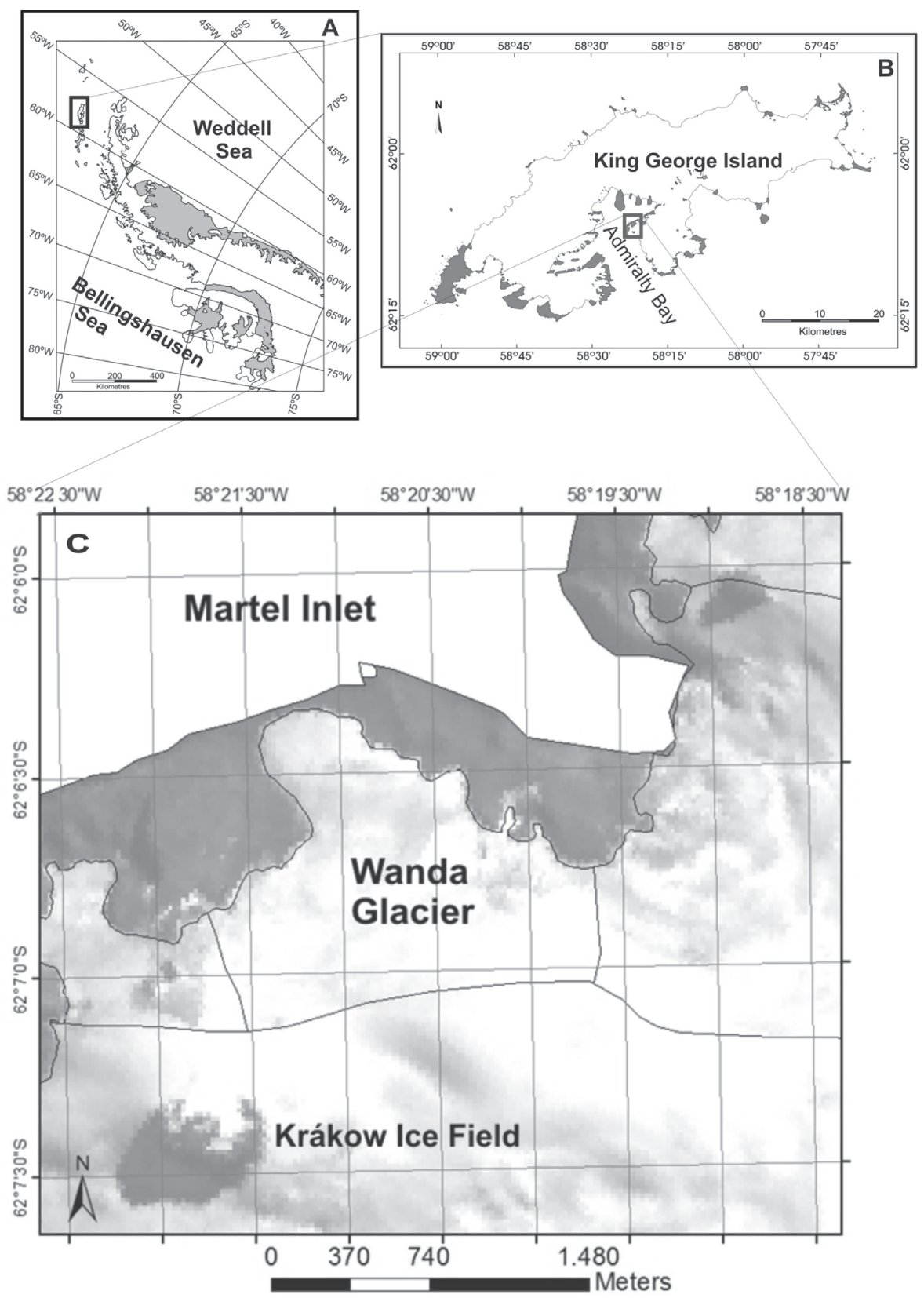

Figure 1 - Location map of Wanda Glacier: (A) Antarctica Peninsula, small square area is detailed in (B) that shows the King George Island; (C) Wanda Glacier is in the Martel Inlet, Admiralty Bay.

transverse GPR data present strong continuous horizontal upper reflectors (HR), these indicate a water table from supraglacial melting processes (Figs. 3-6). There are strong localized (point) reflectors (Figs. 3-6) in the terminus area, possibly representing water filled crevasses. Surface crevasses were observed during field activities. Interpretation classes $H R, H, B R, I D$ and $B D$ in sections respectively represent horizontal reflections, diffraction hyperbolae, bed reflections, diffraction within the ice and bed diffractions.
Characteristics of the internal reflections found in the sections (Figs. 3-6) reveals information about englacial ice. Below the HR there are several isochronous ice layers (Fig. 3). Stronger reflections associated to water in the bed interface correspond to a low velocity zone in the Figure 7 . Scattering noise zones in the ice body (Figs. 3-7) are attributed to water inclusions, such as water lenses or water channels crossed by the radar sections. A strong reflection marks a water table at an average depth of $35 \mathrm{~m}$, which indicates the firn-ice boundary (Fig. 6). But a strong 


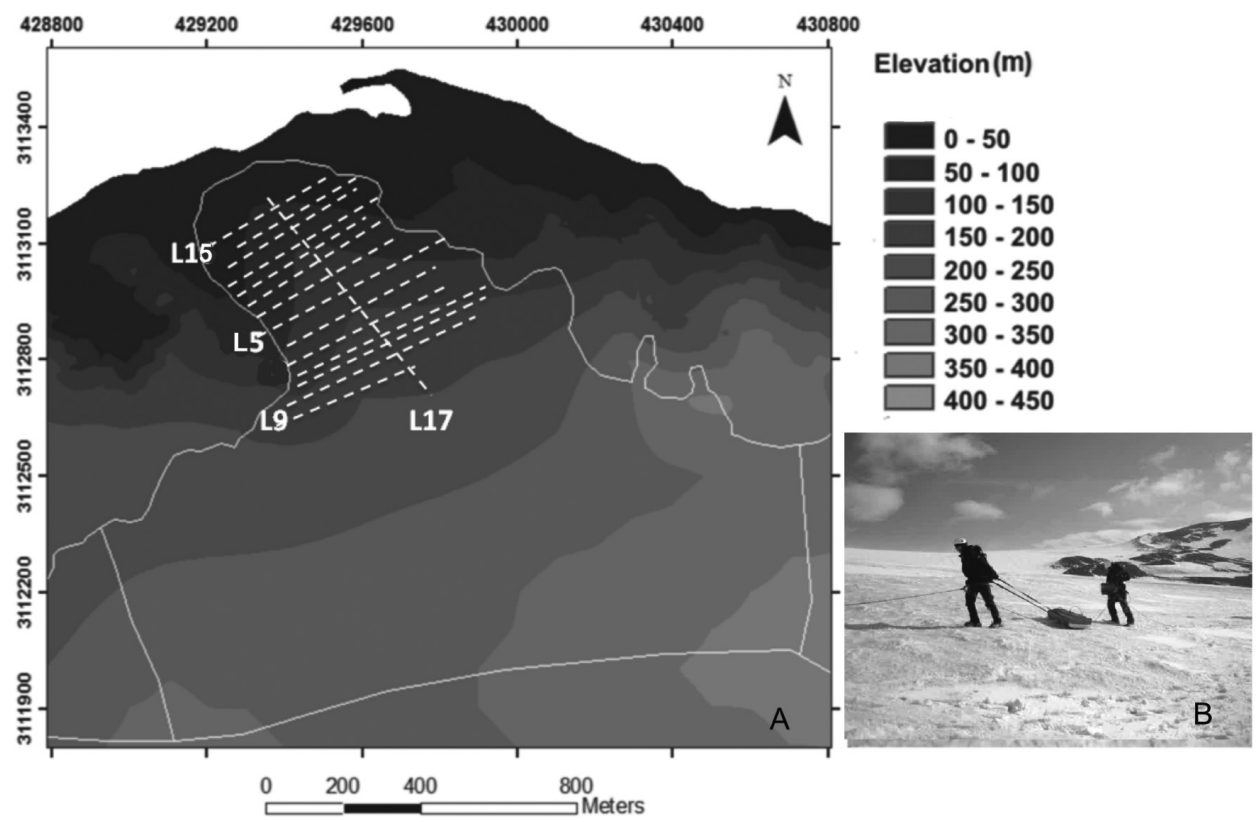

Figure 2 - (A) Location of seventeen GPR common offset sections and one longitudinal section superimposed on the study area topographic map. Sections appear series of white equally spaced line. The four sections $L 5, L 9, L 15$, and $L 17$ referred in this paper are highlighted in the figure. (B) Photograph shows a GPR survey at Wanda Glacier.

reflection due to a supraglacial stream obscures the firn-ice transition in parts of the section (Fig. 5).

Continuous sub-horizontal and steep dipping reflectors in the sections lower zone (Figs. 3-6) are evidences for a film at the ice-bed interface. Semi-continuous dowlappping reflections at the bottom of the radargram can be caused by (Fig. 3) ice-bedrock interface with unfrozen sediments content. Bedrock reflections are interrupted by strongly diffractive parts, masking the bedrock in the sections, and showing an U-shaped valley form.

\section{DISCUSSION}

The surveyed sections strongly suggest the presence of englacial conduits in Wanda Glacier. Water inclusions are seen in the nonmigrated GPR sections as small hyperbolic diffraction features. The migration to aligned the traces with surface location and collapse any possible interfering diffractions. According to Moorman \& Michel (2000), the relative transparency of ice improves the detection of englacial tunnels.

Strong horizon reflections due the presence of a water table are found in the near-surface GPR data. Blindow \& Thyssen (1986) also credited a similar boundary between radar scattering/nonscattering layers in a temperate Austrian glacier to a water table. According to McGee et al. (2003), a water table may be present within macroscale voids that have some hydraulic connection to the bed. There are numerous crevasses in Wanda Glacier, and these are probably important pathways for the surface melting water. Continuous internal reflectors and diffractions (high backscatter) in englacial and subglacial environments constitute further evidence for temperate ice. The glacier water content shows a vertically variable velocity structure obtained for parameters of the scattering hyperbolae migration velocity (Fig. 7), with a lower layer with relatively high water content. We used the water content to provide information about the thermal structure of the glacier. Point scattering within the body of a temperate glacier, typically from macroscale water bodies, is common (Watts \& England, 1976; Jacobel \& Anderson, 1987). According to Jacobel \& Raymond (1984), water bodies in temperate ice are regions with the strongest dielectric contrast because of the large relative permittivity difference between ice and water at radar frequencies. Based on the diffraction hyperbolas polarity, hyperboles near the sections bed is interpreted as water-filled conduits, high water content toward the lower part of the section points to wet ice conditions.

Deeper section firn-ice interface reflections with sub-horizontal layering. The firn-ice transition is also consistent with GPR data from other KGl surveys by Travassos \& Simões (2004); Rückamp et al. (2010) and Blindow et al. (2010).

According to Navarroa et al. (2005), high frequency radars offer a resolution that allows a detailed analysis of the upper glacier surface, allowing a better identification of the firn-ice transition, but this depends on the ice thermal characteristics. 

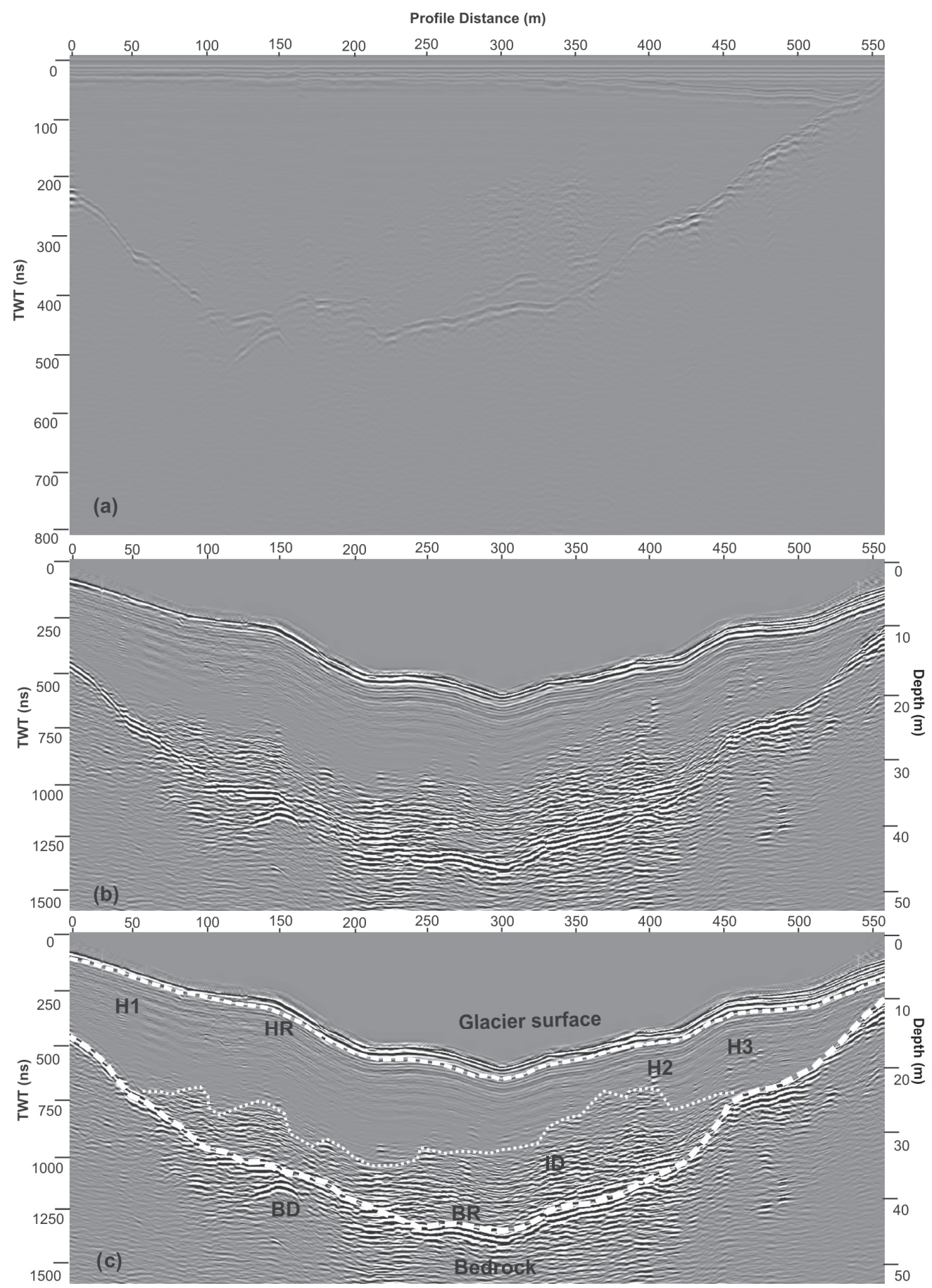

Figure 3 - Section line L15: (a) No processed section; (b) Topography-corrected and migrated radargram; (c) Interpreted radargram. This transversal GPR section crosses the Wanda Glacier from E to W and is located near the glacier terminus. Location of the section line in Figure 2. The upper strong continuous horizontal reflectors (HR) are indicators of one groundwave, and a water table. The high supraglacial water content, indicated by horizontal reflectors near the surface, increases towards the thinner margins. Below HR there is a distinct reflector interpreted as interbedded ice with strong localized point reflectors (englacial water voids). There is a zone of chaotic returns above a cleary defined bed reflection. High water content in the englacial zone is indicated by abundant diffractions (ID). Semi-continuous steep dipping reflectors and point difractions a bed zone are present and reveal water table and debris rich layer in the ice-bed interface. The section provides a cross-sectional view of the strong, quasi-continuous dipping reflection that appears concave-upward, with maximum depths of $25 \mathrm{~m}$. Interpretation classes: HR $=$ horizontal reflections; $\mathrm{H}=$ diffraction hyperbolae; $\mathrm{BR}=$ bed reflections; $\mathrm{ID}=$ diffraction within the ice; and $\mathrm{BD}=$ bed diffractions. 


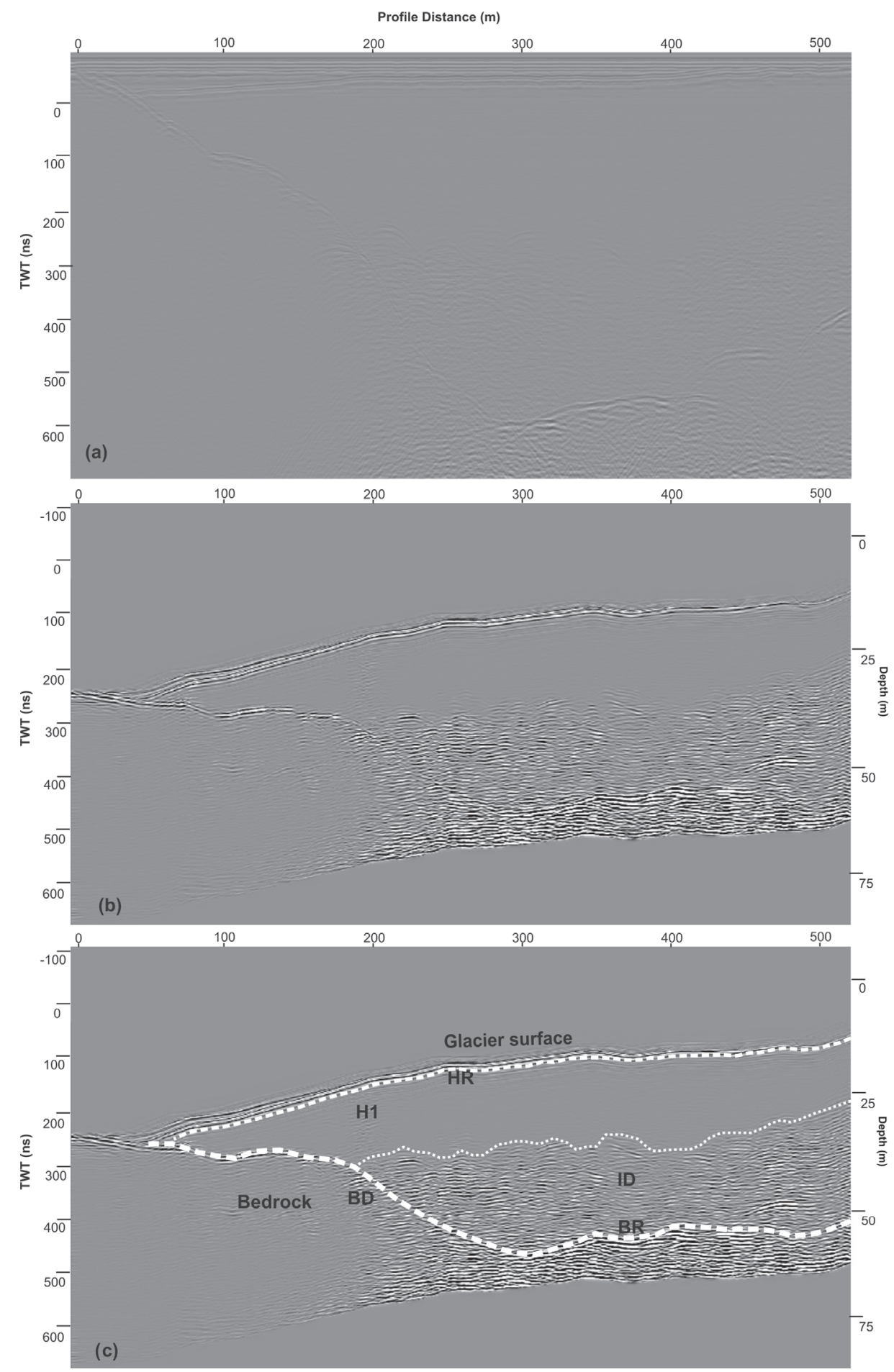

Figure 4 - Section line L5 (Fig. 2): (a) No processed section; (b) Topography-corrected and migrated radargram; (c) Interpreted radargram. This transversal GPR section crosses the Wanda Glacier from W to E along 500 meters. Section line location in Figure 2. Noise near the surface is a strong evidence for water storage from supraglacial streams. A low reflectivity zone (below noise near the surface) can be related with a macroscopic change in permitivity. Abundant diffractions within the ice (ID) denote liquid-water in subglacial environment. Dielectrically dissimilar interfaces within heterogeneous basal ice thereby generate chaotic, noisy returns. Below this layer there are sub-horizontal dowlappping reflectors with continuity that provided evidence for water table in the ice-bed interface. A cluster of bed diffractions can be observed in the central part of the radar section and is an indicator of water and no-frozen sediments filled channels. The average ice thickness is 40 meters. 


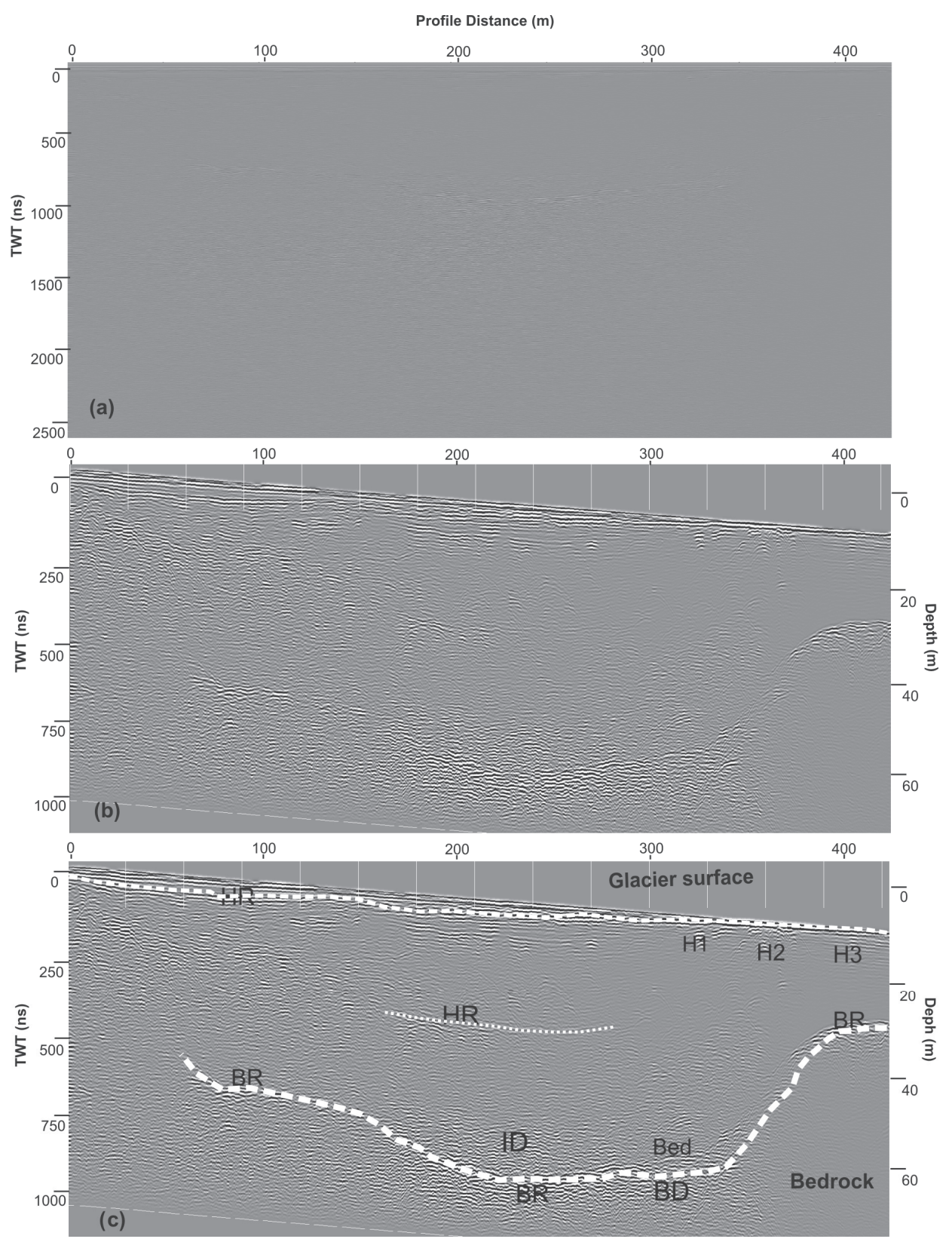

Figure $\mathbf{5}$ - Section line L9 (Fig. 2): (a) No processed section; (b) Topography-corrected and migrated radargram; (c) Interpreted radargram. This transversal GPR section crosses the Wanda Glacier from E to W. Strong surface and bed semi-continuous reflections are evidences for supraglacial and liquid-water percolation. Localized point-source reflector (ID) point to water filled channels in the englacial zone. No continuous bed reflectors can be an evidence for a firn-ice boundary at $35 \mathrm{~m}$ depth in the central section. However, this interface is obscured in many sectors due strong scattering noise in the ice body. Liquid water inclusions also partly obscure bed set horizons reflectors. Dipping slopes of the glacier bed reveal the U-shaped valley topography.

Snow and firn layering within the ice we obscured in sections because the strong surface scattering resulting from the highly inhomogeneous Wanda Glacier ice. According to Arcone (2002), in temperate glaciers the sections shows much scattering due to englacial water bodies.
Sections bed reflections point out to a subglacial topography with smooth slopes. Ice thickness estimation is provided by migrated and topographically corrected sections, assuming a relative dielectric constant for ice of $3 \pm 4$ (Moorman \& Michel, 2000), corresponding to a $0.168 \mathrm{~m} / \mathrm{ns}^{-1}$ average velocity as 


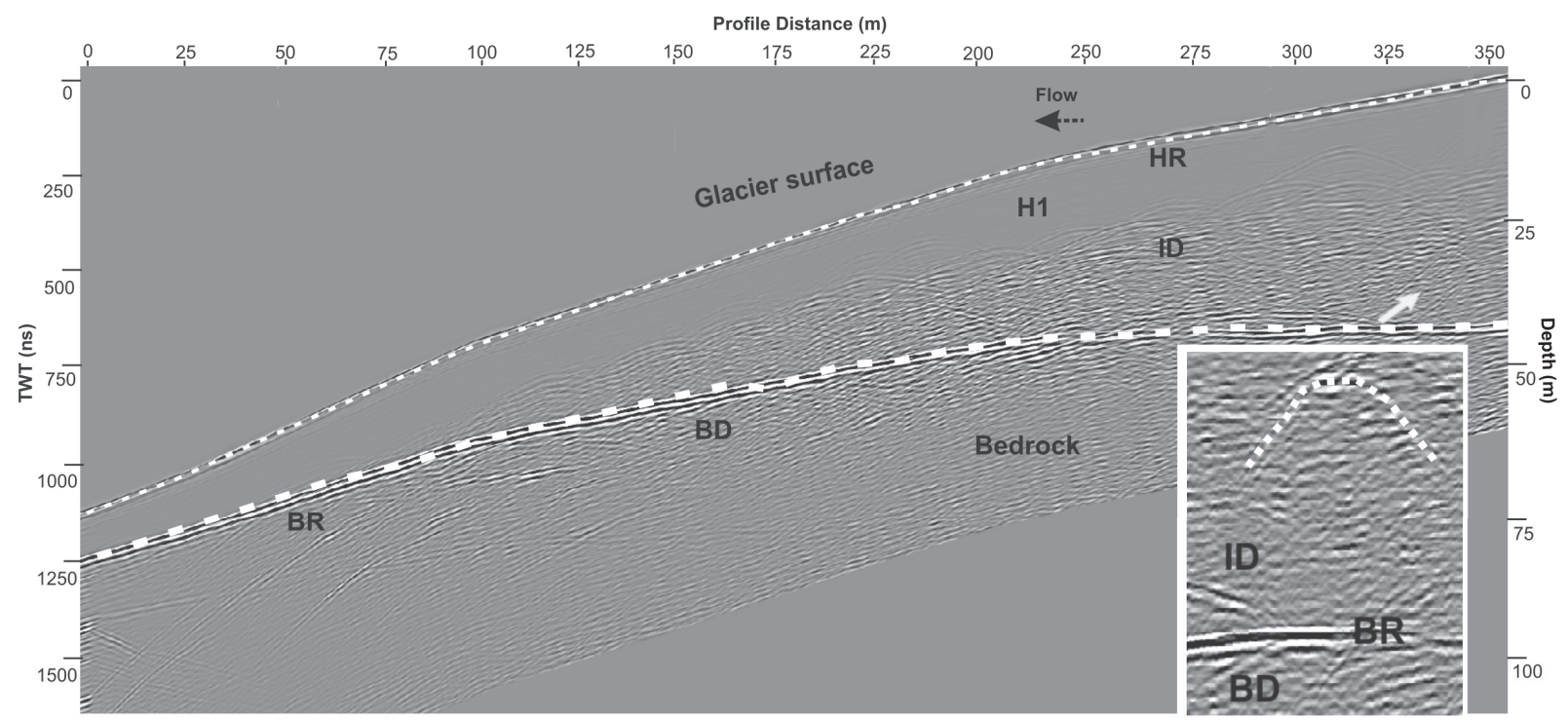

Figure 6 - Section line L17. This interpreted topography-corrected longitudinal radargram is 360 meters long and is located in the central flowline (SW-NE) (Fig. 2). The minimum and maximum ice thickness are about 5 and 35 meters, respectively. Water contact with basal ice is evidenced by strong continuous reflections. The inset shows part of the unmigrated cross-section and presents a hyperbole that is a indicator of the glacial drainage. Stronger sub-horizontal reflector showed in the first part of this section may indicate a liquid water percolating the ice-bed interface towards the glacier terminus. There are dense chaotic returns within the ice body. Excessive diffractions near subglacial zone, toward the end of this section, show more no-frozen sediments and water filled channels interconnected with crevasses. The longitudinal section shows an up-valley dipping reflection at the ice-bed interface as evidence from bedrock topography. Similar reflections are observed in the transverse section at this site. This no-migrated section can portray a distorted image of subsurface stratigraphy.

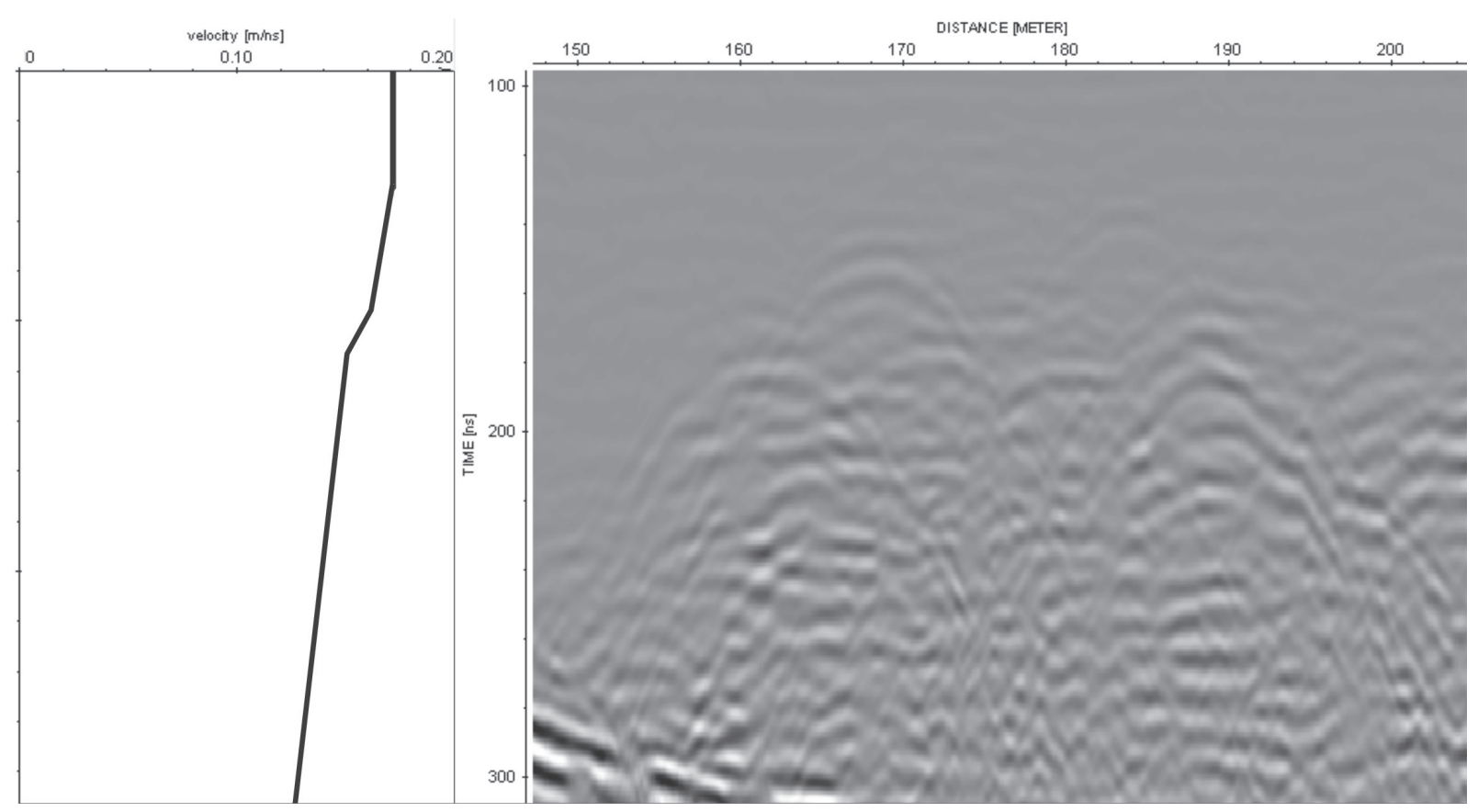

Figure 7 - Part of an unmigrated cross-section (150-200 distance range in section line 15 showed in Fig. 3) shows hyperbolic returns created by point-source reflector at the apex of the curve, and a vertically variable velocity structure with high water content above the bed (more $200 \mathrm{~ns}$ ). 
proposed by studies of Blindow et al. (2010). However, the heavy electromagnetic waves scattering, due to temperate ice inhomogeneities can cause errors in this estimative. The up-turned asymptotes and loss of coherent reflections, found in the sections (Fig. 7), are typical of a low velocity (water) surface, Arcone et al. (1995) identified similar patterns.

The $100 \mathrm{MHz}$ frequency GPR used in this work is considered an appropriate tool for the study of temperate glaciers. However, strong scattering caused by water inclusion at this frequency can obscure firn-ice transition and the detection of bedrock reflections.

\section{CONCLUSIONS}

We used GPR reflections to determine the internal structure and thermal regime of the Wanda Glacier. Migrated and topographically corrected transverse radar sections show strong internal reflectors typical of firn layers. Similar internal structures are observed in other glaciers in KGI. Strong radio waves scattering is attributed to supraglacial, englacial and subglacial meltwater channels. The bed and englacial wet condition were evidenced by radio waves and reveal continuous internal reflectors and diffractions, further evidences for temperate ice in the Wanda Glacier ablation area. Because of its small size $\left(1.5 \mathrm{~km}^{2}\right)$ and thermal conditions, Wanda Glacier responds rapidly to climatic changes and it's relevant for environmental studies.

\section{ACKNOWLEDGMENTS}

This work was supported by the Brazilian National Council for Scientific and Technological Development (CNPq), project 573720/2008-8 and 475478/2013-4. Field logistics provided by the Physical Geography Laboratory - Federal Fluminense University and the Brazilian Antarctic Program (PROANTAR). The authors are grateful for all the help received during fieldwork and also thank Jandyr Travassos for valuable suggestions.

\section{REFERENCES}

ARCONE SA. 2002. Radar profiling at $1500 \mathrm{~ns}$ in firn. In: KOPPENJAN $S \&$ LEE $H$ (Eds.) Proceedings of the Ninth International Conference on Ground-Penetrating Radar, Santa Barbara, California, USA, April 29-May 2, 2002. Bellingham, WA, International Society for Optical Engineering. 433-437.

ARCONE SA, LAWSON DE \& DELANEY AJ. 1995. Short-pulse radar wavelet recovery and resolution of dielectric contrasts within englacial and basal ice of Matanuska Glacier, Alaska, U.S.A. J. Glaciol., 41(137): 68-86.
ARCONE SA, SPIKES VB, HAMILTON GS \& MAYEWSKI PA. 2004. Stratigraphic continuity in $400 \mathrm{MHz}$ short-pulse radar profiles of firn in West Antarctica. Ann. Glaciol., 39: 195-200.

BAMBER JL. 1988. Enhanced radar scattering from water inclusions in ice. J. Glaciol., 34(118): 293-296.

BLINDOW N \& THYSSEN F. 1986. Ice thickness and inner structure of the Vernagfferner (Oetztal Alps): Results of electromagnetic reflection measurements. Z. Gletscherkd. Glazialgeol., 22: 43-60.

BLINDOW N, SUCKRO SK, RUCKAMP MR, BRAUN M, SCHINDLER M, BREUER M, SAURER H, SIMÕES JC \& LANGE MA. 2010. Geometry and thermal regime of the King George Island ice cap, Antarctica, from GPR and GPS. Ann. Glaciol., 51(55): 103-109.

BRADFORD JH \& HARPER JT. 2005. Wave field migration as a tool for estimating spatially continuous radar velocity and water content in glaciers. Geophys. Res. Lett., 32(8): L08502. (DOI: 10.1029/2004GL021770.)

BRAUN M \& RAU F. 2000. Using a multi-year data archive of ERS SAR imagery for the monitoring of firn line positions and ablation patterns on the King George Island ice cap (Antarctica). EARSeL eProceedings, 1: 281-291.

BRAUN M, SAURER H, SIMÕES JC, VOGT S \& GOBMANN H. 2001. The influence of large scale atmospheric circulation on surface energy balance and ablation on King George Island, Antarctica. Inter J. Climat., 21: 21-36.

DANIELS DJ. 1996. Surface Penetrating Radar. IEEE Radar Sonar Navig. Avionics, 6: 300 pp.

DANIELS DJ, GUNTON DJ \& SCOTT HF. 1988. Introduction to subsurface radar. IEEE Proc., F 135(F4): 278-320.

DAVIS JL \& ANNAN AP. 1989. Ground penetrating radar for highresolution mapping of soil and rock stratigraphy. Geophys. Prospect., 37: 531-551.

FERRANDO FA, VIEIRA R \& ROSA KK. 2009. Sobre el calentamiento global en la Isla Rey Jorge: procesos y evidencias en el glaciar Wanda y su entorno. Rev. Inform. Geog., 41: 25-40.

FISHER SC, STEWART RR \& JOL HM. 1996. Ground penetrating radar (GPR) data enhancement using seismic techniques. J. Environ. Eng. Geophys., 1(2): 89-96.

FORSTER RR, DAVIS CH, RAND TW \& MOORE RK. 1991. Snowstratification investigation on an Antarctic ice stream with an X-band radar system. J. Glaciol., 37(127): 323-325.

HUBBERD B \& GLASSER N. 2005. Field Techniques in Glaciology and Glacial Geomorphology. London: John Wiley \& Sons, 400 pp.

JACOBEL R \& RAYMOND C. 1984. Radio-echo sounding studies of englacial water movement in Variegated glacier, Alaska. J. Glaciol., 30(104): 22-29.

JACOBEL RW \& ANDERSON SK. 1987. Interpretation of radio-echo returns from internal water bodies in variegated glacier, Alaska, U.S.A. J. Glaciol., 33(115): 319-323. 
KOHLER J, MOORE JC, KENNET M, ENGESET R \& ELVEHOY H. 1997. Using ground-penetrating radar to image previous years' summer surfaces for mass balance measurements. Ann. Glaciol., 24: 355-360.

McGEE BW, HARPER JT, HUMPHREY NF \& PFEFFER WT. 2003. Water flow through widespread and interconnected void spaces at depth in a temperate glacier. Eos Trans. AGU, 84(46): C11C-0850.

MOORMAN BJ \& MICHEL FA. 2000. Glacial hydrological system characterization using ground-penetrating radar. Hydrological Processes, 14 : 2645-2667.

MURRAY T, GOOCH DL \& STUART GW. 1997. Structures within the surge front at Bakaninbreen, Svalbard, using ground-penetrating radar. Ann. Glaciol., 24: 122-129.

NAVARROA FJ, MACHERETB YY \& BENJUMEAC B. 2005. Application of radar and seismic methods for the investigation of temperate glaciers. J. Appl. Geophys., 57(3): 193-211.

NEAL A. 2004. Ground-penetrating radar and its use in sedimentology: principles, problems and progress. Earth-Sci Rev., 66: 261-330.

PATERSON WSB. 1994. The Physics of Glaciers. Third edition. Oxford, Elsevier. $480 \mathrm{pp}$.

PLEWES LA \& HUBBARD B. 2001. A review of the use of radio-echo sounding in Glaciology. Prog. Phys. Geogr., 25(2): 203-236.

ROSA KK, VIEIRA R, FERRANDO FJ \& SIMÕES JC. 2009. Feições sedimentológicas e geomorfológicas do ambiente de deglaciação das geleiras Wanda e Ecology, ilha Rei George. Antártica. [Sedimentological and geomorfological landforms the deglaciation environment of the Wanda and Ecology glaciers, King George Island, Antarctica] (In Portuguese). Rev. Pesq. Geoc., 37(1): 315-326.

RÜCKAMP M, BLINDOW N, SUCKRO S, BRAUN M \& HUMBERT A. 2010. Dynamics of the ice cap on King George Island, Antarctica - field measurements and numerical simulations. Ann. Glaciol., 51(55): 80-90.

SIMÕES JC \& BREMER UF. 1995. Investigations of King George Island ice cover using ERS-1/SAR and SPOT imagery. Rev. SELPER, 11(1-2): $56-60$.

SIMÕES JC, BREMER UF, AQUINO FE \& FERRONFA. 1999. Morphology and variations of glacial drainage basins in King George Island icefield, Antarctica. Ann. Glaciol., 29: 220-224.

TRAVASSOS JM \& SIMÕES JC. 2004. High-resolution radar mapping of internal layers of a subpolar ice cap, King George Island, Antarctica. Pesq. Antárt. Bras., 4: 57-65.

WATTS RD \& ENGLAND AW. 1976. Radio-echo sounding of temperate glaciers: ice properties and sounder design criteria. J. Glaciol., 17(75): 39-48.

WOODWARD J, MURRAY T, CLARK RA \& STUART GW. 2003. Glacier surge mechanisms inferred from ground penetrating radar: Kongsvegen, Svalbard. J. Glaciol., 49(167): 473-480.

\section{NOTES ABOUT THE AUTHORS}

Kátia Kellem da Rosa is a geographer and PhD in Geography (2012) from Universidade Federal do Rio Grande do Sul (UFRGS). Is professor at the UFRGS. The main research area is glacial geology, geomorphology, sedimentology and Remote Sensing in Antarctic.

Guilherme Borges Fernandez is geographer and specialist in coastal geomorphology. Actually is a coordinator of the Laboratory of Physical Geography at Universidade Federal Fluminense working with landscape evolution and morphodynamics in coastal areas, using Ground Penetrating Radar (GPR), geochronology and high-resolution morphological data. In this work participates in the GPR acquisition and interpretation of the stratigraphic patterns in the Wanda Glacier

Thais Baptista da Rocha is a geographer and receive PhD in Geography in 2013, in Geomorphology, where worked in applications of Ground Penetrating Radar and Geochronology Evolution in Deltaic environments. Currently is a Post-Doc at Universidade Federal Fluminense, in the Laboratory of Physical Geography. The main research area is coastal geomorphology, with implications for coastal management, applied geophysics, coastal quaternary and sedimentary geology.

Felipe Lorenz Simões is a biologist and candidate for a Master's Degree in Animal Biology at the Universidade Federal do Rio Grande do Sul. Contributes to the journal Iheringia, Série Zoologia (Fundação Zoobotânica do Rio Grande do Sul).

Rosemary Vieira. M.Sc. Geography (2002, University of Chile); PhD Geosciences (2006, UFRGS, Brazil); Post-Doc (2010, CPC/UFRGS, Brazil). Areas of expertise include glacial geology, geomorphology, sedimentology and paleoclimatology. Research projects in the Antarctic, and in the Brazilian coastal lakes.

Jefferson Cardia Simões obtained Ph.D. on Glaciology by the University of Cambridge (England). Is Professor at the Universidade Federal do Rio Grande do Sul (UFRGS), and a researcher at the Climate Change Institute (University of Maine, USA). A full member of the Brazilian Academy of Sciences, presently is the Brazilian national delegate to the Scientific Committee on Antarctic Research (SCAR) of the International Council for Science (ICSU). 